\title{
The Discourse of Corruption: Appraisal in Indonesian Media
}

\author{
Albert Tallapessy \\ Jember University, Jember, Indonesia
}

\begin{abstract}
This article discusses corruption case as a discourse. Appraisal theory proposed by Martin and White (2005) is used to analyze the data taken from the Jakarta Post, an Indonesian newspaper written in English. The theory is an extension of Halliday's Systemic Functional Linguistic. It offers the interpersonal relations between participants involved in the context. Appraisal in terms of attitude, engagement, and graduation is critically used to evaluate the collected data. The result of the study shows that the use of strong judgment as indicated by the absence of modality shows that the appraisers try to get public support.
\end{abstract}

Keywords: systemic functional linguistics, appraisal theory, corruption case

\section{Introduction}

Since the reformation movement, Indonesian media has celebrated freedom from government control. The government watch experienced by Indonesian media during the New Order regime disappeared. "In the current political climate, the Indonesian media is able to report openly on a range of previously taboo political issues" (Kramer, 2013, p. 60). Corruption, which is not easily reported on media, becomes the common issue of media reporting. The media freedom resulting from the redrafting of Indonesia Media Bill in 1999 leads to the media's eager to report on corruption cases. There has been no more watchdog activities which formerly conducted by Ministry of Information in the previous era (Sen \& Hill, 2000; Anwar, 2010; Kramer, 2013).

This article discusses corruption as a discourse. Appraisal theory proposed by Martin and White (2005) is used to analyze corruption cases reported in an Indonesian media: the Jakarta Post. The openness of reporting corruption cases constructs two opposing sides of public opinions: pro and against. This situation is used by politicians to gain public support, especially if the party members are involved in corruption cases. Linguistic details in terms of appraisal analysis will be deployed to know how the heated arguments reported in the media leads to the readers' confusion.

\section{Literature Review}

\section{Systemic Functional Linguistics}

Systemic Functional Linguistics (SFL) has been developed by Halliday and others based on the work of Malonowski (1923) and Firth (1957). SFL proposes "category of 'schematic construct' for the analysis of meaning in language" (Hasan, 2005, p. 34). SFL treats context as an element of linguistic theory by operating three parameters: field, tenor, and mode (e.g., Halliday \& Hasan, 1985). Context is a configuration of these three parameters which is called "contextual configuration" (e.g., Hasan, 1999). Furthermore, Hasan claims that "the contextual configuration is critical in the choice of meaning and wording in any occasion of language in 
use" (2005, p. 35). Halliday (1992) explains that system and process are closely related: "the system is shaped by the process of its participation in the talk in the living of life" (Hasan, 2005, p. 35). Furthermore, Halliday (1979) says that there is a close relation between the three context parameters and the internal form of language. Each of the parameters has the potential to activate specific meaning and wordings (Tallapessy, 2011). These meaning and wordings: ideational, interpersonal, and textual are meaning potentials that relate to the most general function of language (Halliday, 1979). These meaning potentials create "the resource for the construal of field, tenor, and mode respectively (Hasan, 2005, p. 35).

The three conceptions of meanings (metafunctions): Ideational, interpersonal, and textual are SFL model of meaning located in the semantic stratum. The ideational metafunction deals with construing experience as a theory of reality and a recourse of reflecting the world (Halliday \& Matthiessen, 1999, p. 7). It consists of two subcategories: experiential and logical:

an experiential, where we represent experience "directly" in terms of happening (actions, events, states, relations), entities that participate in these happenings (person, animate and inanimate object, abstraction) and circumstantial feature (extent, location, time and space, cause, manner, and so on); and "logical", where we represent experience "indirectly" in terms of certain fundamental logical relation in natural language. (Halliday, 1979, p. 59)

The interpersonal metafunction consists of "enacting interpersonal relation through language" (Halliday \& Matthiessen, 1999, p. 7). "Here the semantic system expresses the speaker's intrusion in the speech event: his attitude, evaluation, and judgment; his expectation and demand; and the nature of the exchange as he is setting up" (Halliday, 1979, p. 60). "The textual metafunction is concerned with "organizing ideational and interpersonal meaning as discourse" (Halliday \& Matthiessen, 1999, pp. 7-8). In this metafunction, "the semantic system enables the speaker to structure meaning as text, organizing each element as a piece of information and relating it significantly to what has gone before" (Halliday, 1979, p. 60).

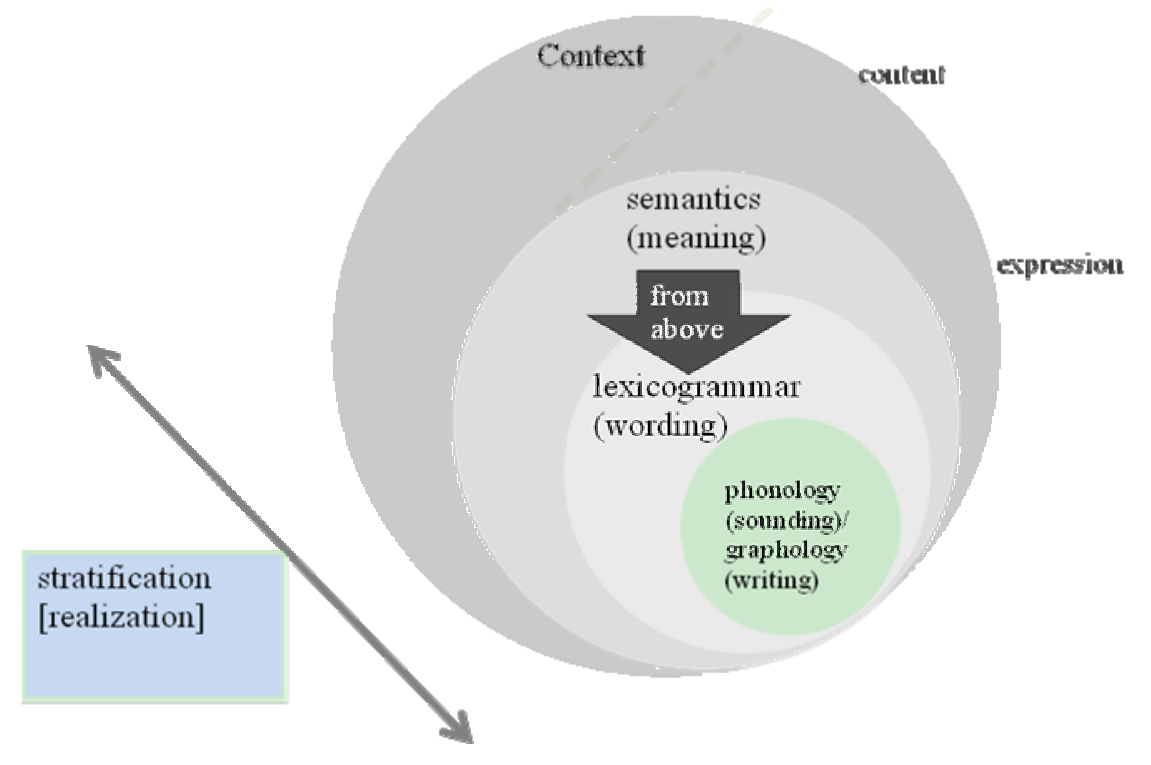

Figure 1. Stratificational model of language and context (Halliday \& Matthiessen, 1999).

At the level of context, these metafunction refer to the three parameters: field, tenor, and mode. Field refers to the setting in which a piece of language occurs; tenor refers to the relationship between participants; 
and mode refers to the channel of communication (Halliday, 1978). "Language in context is interpreted as a system of systems ordered in symbolic abstraction" (Matthiessen, 1993, p. 226). There are five strata where context is located at the highest level, beyond the language system. "The remaining four strata are language internal: Semantics and Lexicogrammar are the elaboration of what Hjelmsleve called content, and Phonology and Phonetics that of expression" (Hasan, 2009, p. 179). Thus, the content plane is realized by the expression plane (Halliday \& Matthiessen, 2004). Semantics and phonology are viewed as interfaces mediating between context and lexicogrammar, and lexicogrammar and phonetics (Teich, 1999).

\section{Register}

Register is a semantic concept which is defined as a meaning in a particular configuration of field, tenor and mode (Halliday \& Hasan, 1985). Field refers to the institutional setting in which a piece of language occurs; tenor refers to the relationship between participants; and mode refers to the channel of communication (Halliday, 1978). According to Halliday (1978), field is the type of social action; tenor is the role of relationship; and mode is the symbolic organization. "The three concepts are related respectively to the ideational, interpersonal, and textual components of the semantic system" (Tallapessy, 2011, p. 40).

Halliday explains that "the notion of register is at once very simple and very powerful" (1978, p. 31) and

provides a means of investigating the linguistic foundation of everyday social interaction from an angel that is complementary to the ethno methodological one; it takes account of the processes which link the feature of the text, considered as the realization of semantic patterns, to the abstract categories of speech function. (Halliday, 1978, p. 2)

Register attempts to uncover the general principles which govern the way. The language that we speak or write varies according to the type of situation (Halliday, 1978).

Matthiessen (1993) claims that register shows "one fundamental element of the organization of language in context" (p. 225). Language in context is organized globally along the dimension of stratification (orders of symbolic abstraction related by realization), metafunctional diversification (modes of meaning), and potentiality (the dimension from potential to initial through instantiation - from system to text) (Matthiessen, 1993).

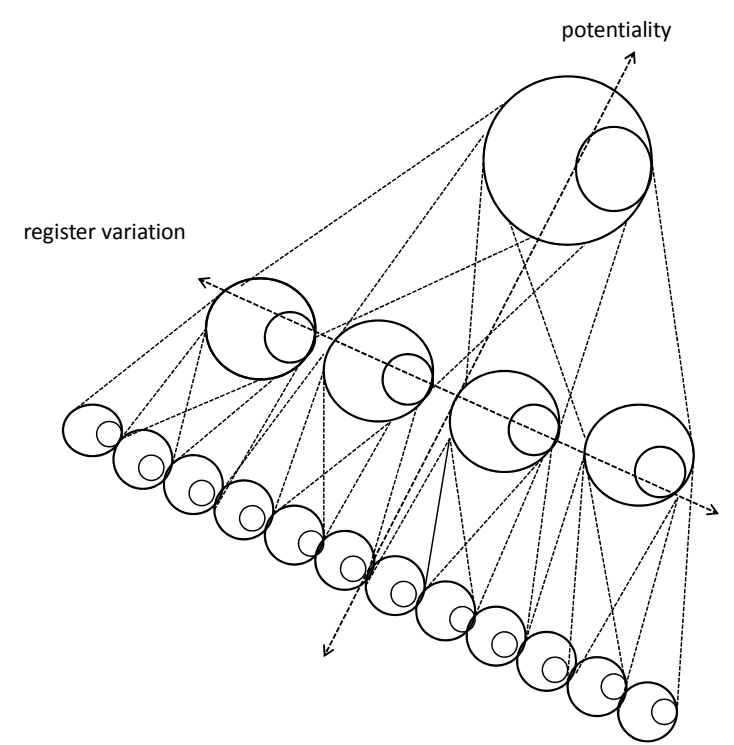

Figure 2. The interaction of potentiality and register variation (Matthiessen, 1993, p. 273). 


\section{Appraisal Theory}

Martin and White (2005) develop appraisal theory based on interpersonal meaning. Appraisal is defined as semantic system for "reacting emotionally (affect), evaluating aesthetically (appreciation), as well as a resource for amplifying and engaging with these evaluations" (Martin, 1995, p. 28). It is through this meaning that a speaker "introduces himself into the context of situation, both expressing his own attitudes and judgments and seeking to influence the attitudes and behavior of others (Halliday, 2007, p. 184). The interpersonal function is "realized through the system of Modality which allows for the expression of opinions relating to probability/usuality (modalization) and obligation/inclination (modulation) (Hart, 2014, p. 44). According to Martin and White, appraisal is a meaning potential located at the semantic level, which is then realized in the level of lexicogrammar through: Attitude, Engagement, and Graduation (Martin \& White, 2005).

Attitude is "the central of evaluative process" (Meadows \& Sayer, 2013, p. 104). It deals with the speaker or writer's feelings and opinions. They are divided into affect, judgment, and appreciation. Affect refers to positive or negative feeling, while judgment is concerned "with attitudes towards behavior, which admire, criticize, praise, or condemn" (Martin \& White, 2005, p. 43), and "appreciation involves evaluations of semiotic and natural phenomena, according to the ways in which they are valued or not in a given field" (Martin \& White, 2005, p. 43). Engagement and graduation, on the other hand, are discursive resources functioning as a "scale intensity of degree" of attitude, in terms of graduation, and to "adopt a position with respect to proposition" in terms of engagement (Martin \& White, 2005, pp. 39-40).

\section{Method}

Six corruption case texts reported by the Jakarta Post from 2013 to 2015 were taken as samples to analyze. Appraisal theory based on SFL model is used to analyze the data. Appraisal in terms of attitude, engagement, and graduation is critically operated on the data.

\section{Result and Discussion}

Text 1 is an excerpt from corruption case that involved the president of Prosperous Justice Party:

The latest corruption case revealed by the Corruption Eradication Commission (KPK) has shocked the country, largely because it involves the Prosperous Justice Party (PKS), which had no significant record of corruption. More than that, the case involves one of the most respected symbols of the party; its chairman. Until recently, probity was a very significant selling point for the party in attracting voters. Therefore, many believe the KPK arrest of the former PKS chairman Luthfi Hasan Ishaaq marks an end for the party because many of its supporters will abandon the party in the 2014 elections. While the possibility of losing credibility is understandable, the possibility of PKS extinction is difficult to accept at least based on the two following arguments. The significance of the PKS in Indonesian democracy stretches far beyond the Indonesian border. As an Islamic party, it represents the argument that Islamic elements can work in a democracy with few problems. As long as it can exist in Indonesian politics it will prove that Bernard Lewis is wrong to argue that Islam is the source of the democratic deficit in the Middle East. The Middle East has been seen as the most pertinent example of how Islam can be viewed in relation to democracy and its reputation is not too convincing in the eyes of many scholars, as Lewis argues. The Arab Spring brings a new hope that the fall of authoritarian or semi-totalitarian regimes will be replaced by democratic forces.

The text above is one of a number of comments reported in Indonesian media in respond to the arrest of Lutfi Hasan, the president of Prosperous Justice Party (PKS), an Islamic party which was believed as a clean party. The appraiser does not believe that this happen on such a party. The use of positive feeling as: no significant record of corruption, very significant selling point, and understandable are the examples how he evaluates the party. The 
appraiser believes that this case will decrease the PKS voter in 2014 general election.

Text 2 is an excerpt from PKS elites' responds toward the corruption case:

The party's members are convinced Luthfi is innocent and that the only explanation for the Corruption Eradication Commission's (KPK) charging him with graft is the work of a "conspiracy". Some party members alleged that it could be the work of its political enemies, but senior PKS politician Hidayat Nur Wahid went the furthest, suspecting that the Jews could be involved. Hidayat said there were parties within the country and beyond who did not want his party to grow bigger for a number of reasons, including the fact that it had been consistently supporting the rights of the Palestinians under Israel's oppression. "They could be the Zionists", Hidayat told reporters at a press conference at the party's headquarters on Friday.

Responding the above news, the PKS elites and the party members believe that Lutfi is innocent. The attributives convinced, conspiracy, bigger show how the party members reject their leader's arrest by the Corruption Eradication Commission (KPK). They claim that it is the work of a conspiracy. The senior PKS politician argues that the Zionist is behind the case. However, the use of modality: could be, shows that he himself is doubt of his statement.

The two texts above show the corruption case which became the headlines of a number of Indonesian media in 2013. The following two texts are other corruption cases which got national attention at the beginning of 2015 .

Text 3 is an excerpt from General Budi Gunawan case:

The Corruption Eradication Commission (KPK) rejected on Monday all arguments against the prosecution of National Police chief nominee Comr. Gen. Budi Gunawan, whom the antigraft body recently named a suspect in a graft case. In the first session of a pretrial hearing to challenge Budi's suspect status, his lawyers claimed the antigraft body had abused its power by naming the three-star police general a suspect without questioning him and presenting witnesses. The lawyers also alleged that the KPK had breached its collective decision-making mechanism in which all five KPK commissioners are required to approve a decision to name a person a suspect. They also said that the KPK had acted unethically for announcing an investigation into Budi just days after President Joko "Jokowi" Widodo nominated him for the chief post. One of Budi's lawyers, Maqdir Ismail, said the KPK was wrongly prosecuting Budi in the case as his status at that time was not a "law enforcer" because his position as the head of the Career Development Bureau at the National Police from 2004 to 2006, when his alleged crime took place, did not grant him any investigative authority.

The case emerged when Indonesian President Joko Widodo nominated Comr. General Budi Gunawan as National Police chief. Soon after the nomination, KPK named the General as the suspect of a graft case. Soon, Indonesian media reported the pro and against opinion on this nomination. Text 3 above discuses how General Budi' Lawyers reject all argument proposed by KPK. The lawyers express their judgment on how KPK named Comr. Gen Budi as a suspect in a graft case. The words had abused, unethically, wrongly prosecuting; show their disappointment on the KPK decision.

The following two texts describe the conflict between Jakarta Governor, Basuki Cahaya Purnama and the city councilors dealing with the 2015 draft budget. The governor found many irregularities in the draft which he believed that a number of city councilors were behind the irregularities. The news reported in almost Indonesian media, including the Jakarta Post, got attention not only by the Jakarta residents but also other residents around Indonesia.

Text 4 is an excerpt from the Jakarta Governor:

Governor Basuki "Ahok" Tjahaja Purnama revealed that he found many irregularities in the draft 2015 budget, the deliberation of which he personally monitored. Ahok said that while going over the budget draft, he found $\mathrm{Rp} 8.8$ trillion (US\$ 698.7 million) that was to be allocated for socializing governor's decree". "I was confused. There were thousands of 
such allocations. What is that much funding even for? So I crossed out that budget allocation manually with my pen and highlighter and wrote 'you wish!'” Ahok told reporters at City Hall in Central Jakarta recently. He said that he was suspicious that a number of city councilors were behind the irregularities, although he refused to name names. Ahok said that he would continue to closely monitor the budget draft along with regional secretary Saefullah, Jakarta Financial Management Board head Heru Budi Hartono and Jakarta Development Planning Board head Tuty Kusumawati, before it is approved.

The extract above shows how the governor judges that the city councilors are the source of the conflict. The attributives confused and suspicious indicate the appraiser's negative judgment toward the city councilors. This judgment was denied by the council leader who claimed that the governor's suspicion was unreasonable as shown by the following text.

Text 5 is an excerpt from the council leader:

Prasetio said there was no such thing as random allocations amounting to trillions of rupiah in the 2015 budget. "We met with Pak Ahok to clarify the news report. There were no such allocations. It was merely a misunderstanding", he said. Prasetio explained that he had been busy and the Council had yet to submit anything to the Jakarta Development Planning Board (Bappeda). If indeed there were any irregular programs inserted into the budget draft bylaw, Prasetio said, "it must have been done by an irresponsible [council] member". "Pak Ahok should directly ask this particular person because the remaining 105 councilors basically have no problem with the budget", he added. Triwisaksana said that a number of relevant officials, including the city secretary, the Bappeda head, and staff from the Jakarta Financial Management Agency and the Jakarta Inspectorate, were also present during the meeting "to solve the misunderstanding".

The above extract shows how the council leader denied the governor's suspicion. He claimed that it was only misunderstanding. The words busy and irresponsible are the appraised words used by the council leader to respond the governor's suspicion.

The corruption cases like those presented above are easily found in today Indonesian media. Something that was taboo in the previous regime has become entertainment. "The desire to report openly on corruption case becomes almost an obsession in Indonesia following decades of media censorship on the issue" (Kramer, 2013, p. 61). Kramer further explains that there are two reasons behind this: to make politics accountable, and to improve government transparency. Although there is a number of reporting styles, reporting corruption as political scandal increases greatly (Margana, 2009). The above texts also indicate that judgment is easily used to support or to deny any suspicion on corruption cases.

\section{Conclusion}

This paper has demonstrated how corruption cases become entertainment in Indonesian media. Appraisal theory developed by Martin and White (2005) has been used to analyze how the appraiser on each example operates his/her attitude in terms of affect, judgment, or appreciation to show his/her feeling towards the case. By operating interpersonal meaning the journalists may use the attributives to show their side on the corruption case. Bias and power may result in the text appraised.

\section{References}

Anwar, D. F. (2010). The Habibie presidency: Catapulting towards reform. In E. Aspinal \& G. Feally (Eds.), Soeharto's new order and its legacy: Essay in the honor of Harold Crouch. Canberra: ANU E Press.

Halliday, M. A. K. (1978). Language as social semiotic. London: Edward Arnold.

Halliday, M. A. K. (1979). Modes of meaning and modes of expression: Type of grammatical structure, and their determination by different semantic function. In D. J. Allerton, A. Carney, \& D. Holdcroft (Eds.), Function and context in linguistic analysis. Cambridge: Cambridge University Press. 
Halliday, M. A. K., \& Hasan, R. (1985). Language, context, and text: Aspect of language in social-semiotic perspective. Melbourne: Deakin University.

Halliday, M. A. K. (2007). Language as social semiotic: Towards a general sociolinguistic theory. In J. Webster (Ed.), Language and society (pp. 169-202). London: Continuum.

Halliday, M. A. K., \& Matthiessen, C. M. I. M. (1999). Construing experience through meaning. London: Cassel.

Hart, C. (2014). Discourse grammar and ideology functional and cognitive perspectives. London: Bloomsbury.

Hasan, R. (1999). Speaking with reference to the context. In M. Ghadessy (Ed.), Text and context in functional linguistics (Vol. 169). Amsterdam: John Benjamins Publishing Company.

Hasan, R. (2005). Language society and consciousness. London: Equinox.er.

Kramer, E. (2013). When news becomes entertainment: Representation of corruption in Indonesia's media and the implication of scandal. Media Asia, 1(40), 60-72.

Matthiessen, C. M. I. M. (1993). Register in the round: diversity in a unified theory of register analysis. In M. Ghadessy (Ed.), Register analysis. New York: Pinter Publisher.

Margana, S. (2009). Akar historis korupsi di Indonesia (Corruption historical root in Indonesia). In Wijayanto \& R. Zachrie (Eds.), Korupsi mengkorupsi Indonesia (Corruption corrupts Indonesia) (PP. 417-442). Jakarta: PT Gramedia Pustaka Utama.

Martin, J. R. (1995). Interpersonal meaning, persuasion and public discourse: Packing semiotic punch. Australian Journal of Linguistics, 15(1), 33-67.

Martin, J. R., \& White, P. R. R. (2005). The language of evaluation appraisal in English. New York: Palgrave Macmillan.

Meadows, B., \& Sayer, P. (2013). The Mexican sports car controversy: An appraisal analysis of BBC's top gear and the reproduction of nationalism and racism through humor. Discourse, Context and Media, 2, 103-110.

Sen, K., \& Hill, D. T. (2000). Media, culture and politics in Indonesia. Oxford: Oxford University Press.

Tallapessy, A. (2011). The many modes of meaning in Javanese shadow play: A systemic functional approach to the dalang technique and to the changing context of audience reception (Unpublished thesis, Macquarie University, Sydney).

Teich, E. (1999). Systemic functional grammar in natural language generation: Description and computational representation. London: Cassel. 